\title{
Outdoor thermal comfort in the old desert city of Beni-Isguen, Algeria
}

\author{
Fazia Ali-Toudert ${ }^{1, *}$, Moussadek Djenane $^{2}$, Rafik Bensalem ${ }^{3}$, Helmut Mayer ${ }^{1}$ \\ ${ }^{1}$ Meteorological Institute, University of Freiburg, Werderring 10, 79085 Freiburg, Germany \\ ${ }^{2}$ Department of Architecture, University Mohamed Khider, 7000 Biskra, Algeria \\ ${ }^{3}$ School of Architecture of Algiers, EPAU, PO Box 2, El-Harrach, 16000 Algiers, Algeria
}

\begin{abstract}
The present study addresses the issue of outdoor thermal comfort in a hot and dry climate in relation to urban geometry. This experimental work, conducted in an old desert city, aims to provide some quantitative knowledge on the effectiveness of traditional design forms in ensuring a comfortable thermal environment outdoors under extreme summer conditions. The study focused on the role of the geometry of urban canyons. Air temperature, air humidity and wind speed were measured during summer 2003 in various urban streets in the old Saharan city of Beni-Isguen, Algeria $\left(32.40^{\circ} \mathrm{N}\right)$. The short-wave and long-wave radiation fluxes received by a human body from the 3D surroundings were also measured in order to allow an accurate calculation of the heat gained by a pedestrian. Bio-meteorological methodology was used and thermal comfort was expressed by means of the physiologically equivalent temperature (PET) index. The results show that the heat stress in a hot-dry climate is very high in unobstructed locations in contrast to sheltered urban sites. The vertical street profile is of prime importance in the resulting thermal sensation. Building materials were also found to play a decisive role. Deep streets together with high thermal capacity materials mitigate the heat stress in the daytime. The high and heavy walls provide more shading and more heat storage, leading to lower surfaces temperatures. Hence, a human body absorbs less short-wave radiation owing to reduced direct exposure, and also less radiant heat from the surrounding environment is absorbed by the body. In contrast, air temperature and air humidity show little dependence on the urban geometry. Therefore, these factors are less relevant indicators for outdoor thermal comfort in the summertime.
\end{abstract}

KEY WORDS: Thermal sensation $\cdot$ Street geometry $\cdot$ Street orientation $\cdot$ Hot-dry climate $\cdot$ Vernacular architecture $\cdot$ Physiologically equivalent temperature $\cdot$ PET

\section{INTRODUCTION}

The Mzab valley in the Algerian Sahara is characterized by 5 compact cities, each of them possessing an oasis. These cities, built in the 10th century and designated world culture heritage buildings by UNESCO since 1982, provide in addition to an architectural authenticity (Donnadieu et al. 1977, Ravérau 1981) a climatic-conscious design developed over centuries of building experience.

It is commonly claimed that this type of compact urban structure is perfectly adapted to suit the surrounding climatic environment. However, this has not been proven and the current knowledge on this issue is still mainly qualitative. The climatic effectiveness of traditional solutions has been questioned, as these also reflect cultural specificities (e.g. Givoni 1997). The positive climatic effects of numerous traditional solutions may have been overestimated: Givoni (1997) and Meier et al. (2004) argue that the excessive thermal inertia of such architecture in hot-dry climates prevents the nocturnal cooling of the houses and leads to discomfort indoors at night. Also, Ouahrani (1993) found that day-lighting is insufficient in the typical inward-looking houses because of the small size of the courtyard, which is the only source of natural light. 
Thus, more investigation is required to quantitatively evaluate common design concepts and establish the veracity of this common belief of climatic adaptation. Furthermore, available studies undertaken in such built environments focused on the architectural dimension, i.e. indoor climate (e.g. Ouahrani 1993, Krishan 1996, Potchter \& Tepper 2002, Meier et al. 2004), whereas very few published studies are available to date which deal with the urban design level, i.e. outdoor spaces (e.g. Grundström et al. 2003).

This experimental work focuses on the assessment of human comfort in relation to traditional design forms. This field study complements numerical simulations conducted for the same location (Ali-Toudert \& Mayer 2005). Furthermore, eventual comparison with more field studies to be conducted in new settlements in this region is also foreseen. The final goal is to use the information gathered from these studies in designing contemporary houses for hot-dry climates.

\section{THE TRADITIONAL CITIES OF THE MZAB VALLEY}

\subsection{Climate conditions and comfort requirements}

Clear skies are a characteristic of the Saharan climate, resulting in a comparatively high solar irradiance in the daytime and a high long-wave net radiation during the night. Therefore, the summer is hot and dry, as well as long, owing to the subtropical location of the region. Air temperature $\left(T_{\mathrm{a}}\right)>40^{\circ} \mathrm{C}$ is not rare and the daily $T_{\mathrm{a}}$ amplitude is relatively large. The atmospheric moisture content is low, with a relative humidity $(R H)$ below $35 \%$ or a vapour pressure $(V P)$ of about $12 \mathrm{hPa}$. In most places, the wind sweeps dust and sand for several months of the year. The winters are short and cold, particularly at night (reaching freezing point). Rainfall is scarce but of high intensity when it occurs (ONM 1985). Mean values of $T_{\mathrm{a}}, R H, V P$ and wind speed $(v)$ for the hottest month of August during the decade 1975-1984 for Ghardaia (capital of the Mzab valley) are given in Fig. 1.

The living conditions for people are very difficult in hot-dry climates. However, they can be improved by using an appropriate housing design. A number of strategies have been recommended (e.g. Koenigsberger et al. 1973, Golany 1982, Golany 1996, Givoni 1997). These include fabric compactness, the high inertia of the construction, shading, night ventilation and evaporative cooling. In the winter season, provision for sunshine is recommended with heat storage capacity.
The Mzab cities typically illustrate these recommendations. The old settlements in the Mzab valley form a system where environmental concepts can be stated at the 3 consecutive design scales; (1) the location in the valley, (2) the urban fabric, and (3) the architecture of the house.

\subsection{Implantation in the Mzab valley}

In the Sahara, water availability and protection from hot and dusty winds are important considerations when choosing a site for habitation. The Mzab valley, for example, supplies water and shelter from the hot winds. Settlements called ksours are built on rocky mountain peaks, which overhang the valley, in order to prevent flooding. Precipitation is a real danger because of its intensity, though it is rare. The valley is a natural water reservoir and hence a fertile area reserved for agriculture, i.e. in form of oases (Fig. 2). An ingenious watering system is integrated into the street layout inside the palm groves. A number of channels drain rain water to deep wells, from which it is brought back to the surface when needed and collected in basins. The water is routed to each of the private plots according to old water rights.

The ksours are usually located on the southern slopes of rocky plateaus to protect them from northerly winds and to take advantage of sun exposure, while benefiting from the sand filtering effect of the nearby palm grove. The trees intercept solar radiation, reduce wind speed and filter the Saharan dust. The evaporation and evapo-transpiration from the soil and the vegetation, respectively, increase the air humidity. The oases are garden cities used as secondary residences during the

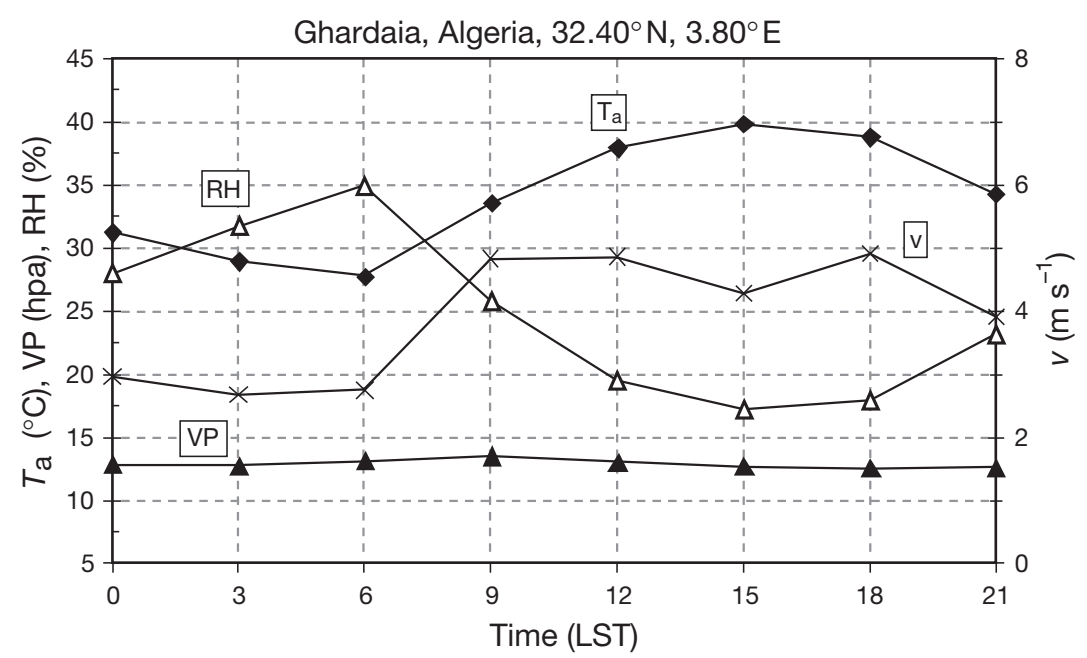

Fig. 1. Long-term (1975-1984) mean values of air temperature $\left(T_{\mathrm{a}}\right)$, relative humidity $(R H)$, vapour pressure $(V P)$ and wind speed $(v)$ in August at Ghardaia weather station, Mzab valley, Algeria $\left(32.40^{\circ} \mathrm{N}, 3.80^{\circ} \mathrm{E}\right)$ 


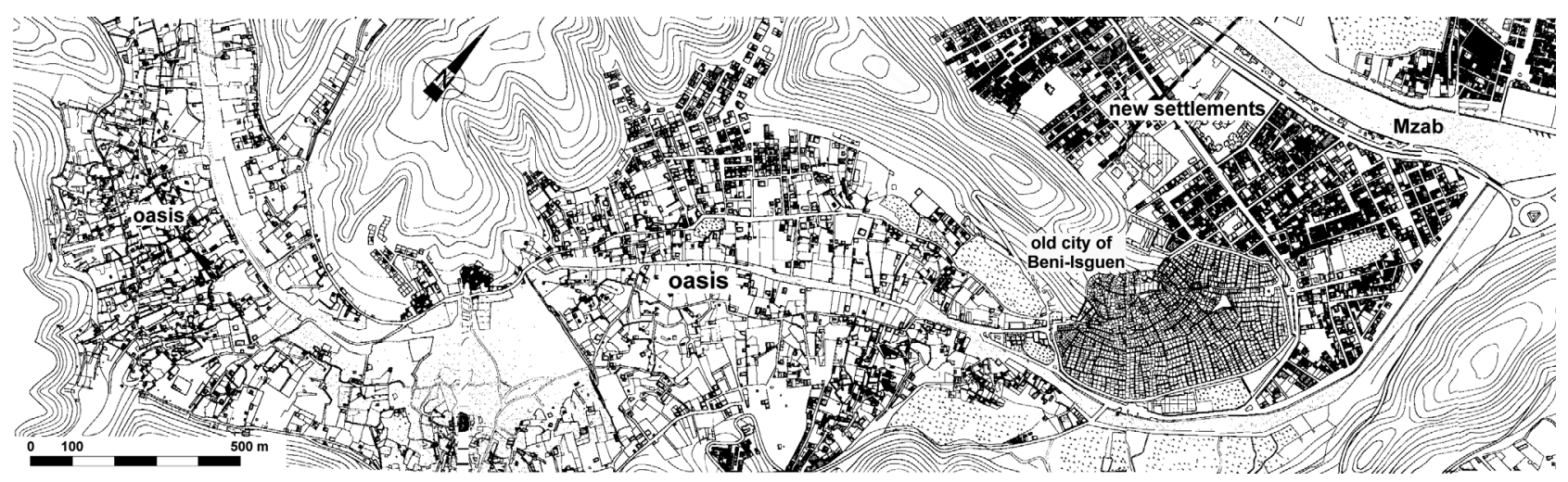

Fig. 2. The old city of Beni-Isguen and its oasis in the Mzab valley, Algeria

hot season since these offer a more comfortable microclimate, i.e. freshness and shade. The houses inside the palm groves are of less compact construction and have more openings to the surroundings than those in the ksours, and confirm a climate-conscious design.

\subsection{Urban fabric}

The urban structure reveals the distinctive influence of the climatic conditions, which are just as important as the cultural dimension. The medium height houses are inward-facing buildings allowing an extreme compactness of the urban fabric (Fig. 3). Only the rooftops and a few facades are exposed to the intense solar radiation. The streets are very narrow and shaded by the neighbouring walls, in some places also covered or further protected from the sun with trellis, cloth and awnings.

A solar right is rigorously observed (Donnadieu et al. 1977). Explicitly, no house may be cut-off from the direct solar radiation by the neighbouring houses in the cold season. Therefore, the building height is limited by the maximum height attained by the sun in winter.

The thermal inertia of the whole system is high, as a consequence of a minimal envelope to volume ratio (compactness) and also owing to the use of heavy materials, mainly stone, which has a high thermal capacity. The mostly horizontal configuration of the city increases the urban albedo, as noted by Aida \& Gotoh (1982). The use of light colours (houses are generally whitewashed or painted in light colours) would further increase the urban reflectance (twice as much as modern cities; Taha et al. 1997). The roofs, being the main exposed surfaces, need to be carefully designed. These are flat and heavy, allowing, on one hand, a minimal conduction of heat indoors, because of a high diurnal heat storage capacity, and on the other hand, a rapid night-time release of heat ensured by a large sky view factor, SVF (close to 1.0). The placement of the cities on hill slopes supports ventilation within the streets despite the compact typology.

\subsection{Architecture of the houses}

Self-shading and thermal inertia are important for indoor comfort. The intense solar radiation is generally controlled through the use of deep courtyard configu-

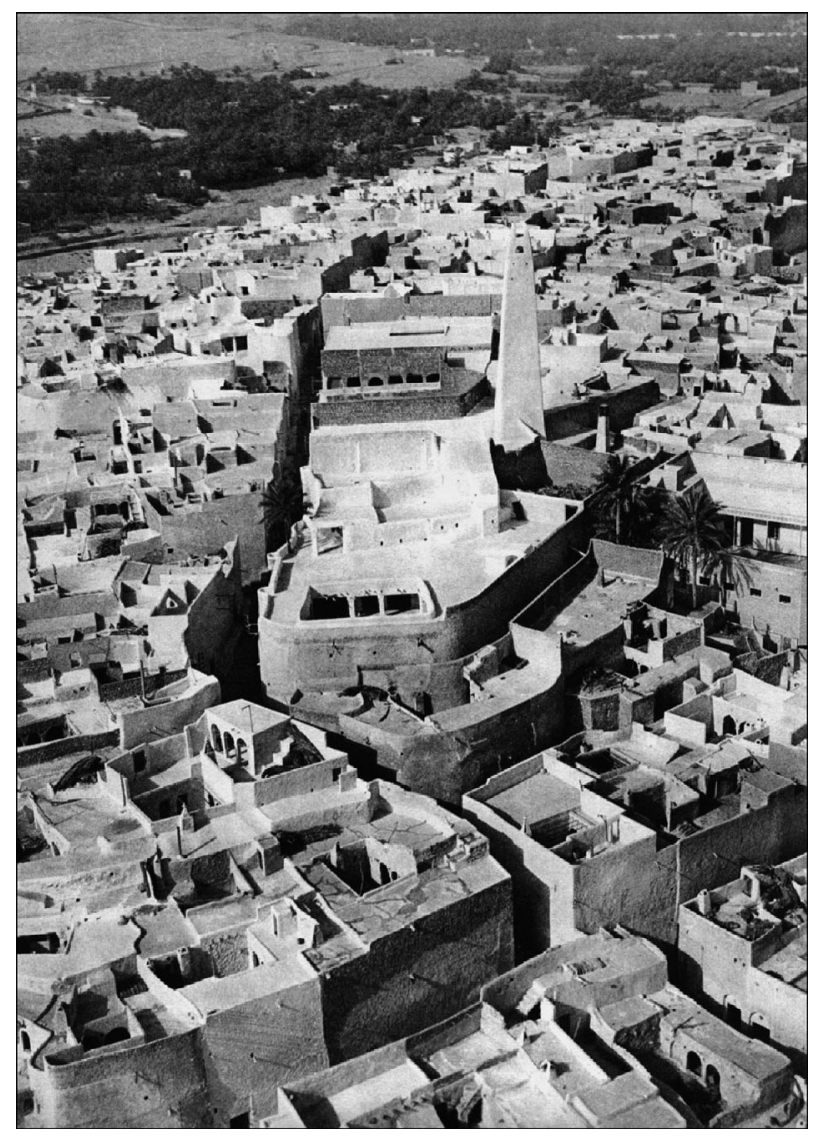

Fig. 3. A view of the compact urban fabric of the upper part of the old city of Beni-Izguen (Roche 1970) 
rations and the extreme clustering of houses. The house design further controls radiant heat and glare through the use of superimposed courtyards. The courtyard is the main source of light as the outside facades generally are windowless. On ground level, there is a skylight that can be covered with a lattice screen. This level and underground spaces are refuges during the hottest time of the day. Moreover, the walls made of stone and gypsum together with their whitewashed coloured surfaces further prevent daytime summer overheating. Even if these houses were built to cope primarily with very hot and long summers, the winter conditions are improved with the southern orientation of the semi-outdoor living spaces on the terraces (galleries) and by taking advantage of the heat storage capacity of the buildings (Ravérau 1981). Air movement occurs through small openings in the walls, and doors are left open most of the time. Thermal differences between the cool street, the house and the warm terrace may promote indoor ventilation.

Even though the urban fabric and the building envelope are the main climatic filters, the people of these cities also show adapation to the severe thermal regime by employing a 'nomadic' way of living in their houses. Spaces within the houses have to be nonspecialized or duplicated (e.g. being able to cook both indoors or outdoors). During summer when thermal conditions are extreme, people will move to their summer houses in the cooler palm grove. They also tend to go outside either early in the morning or in the late afternoon, when the solar radiation is less intense.

\section{OUTDOOR THERMAL COMFORT}

The microclimate of an urban street canyon is relatively well documented from studies conducted in midlatitude cities. Street orientation and aspect ratio (or height-to-width ratio, $\mathrm{H} / \mathrm{W}$ ) were found to be the most relevant urban describers in relation to urban microclimatic changes. Both were found to be decisive in the energy balance of an urban canyon (e.g. Nunez \& Oke 1977, Todhunter 1990, Yoshida et al. 1990/1991), in a differentiated potential of irradiation of the canyon facets, i.e. floor and walls (Arnfield 1990a, Bourbia \& Awbi 2004), as well as in the wind flow at street level (e.g. Nakamura \& Oke 1988, Santmouris et al. 1999). Canyon facets surface temperatures influence the amount of the heat transferred to air as sensible heat, and are noticeably higher in exposed situations than in shaded situations (Nakamura \& Oke 1988, Yoshida et al. 1990/1991, Santamouris et al. 1999). Yoshida et al. $(1990 / 1991)$ reported that temperatures of shaded surfaces can be lower than the canyon air. $T_{\mathrm{a}}$ is weakly affected by the urban canyon geometry for $\mathrm{H} / \mathrm{W} \approx 1$ and shows insignificant variance from that measured above roof level, owing to good mixing of canyon air (Nakamura \& Oke 1988). Yet air stratification may take place in the canyon volume at higher aspect ratios (Santamouris et al. 1999). Coronel \& Alvarez (2001) and Grundström et al. (2003) reported that measured air temperatures at street level in-canyon were 8 and $10 \mathrm{~K}$ lower in relation to a free location in a hot summer period for streets with $\mathrm{H} / \mathrm{W}$ ratios of 5 and 10, respectively. Ali-Toudert \& Mayer (2005) report on a maximum difference of $3 \mathrm{~K}$ between wide and deep streets with $\mathrm{H} / \mathrm{W}=0.5$ and $\mathrm{H} / \mathrm{W}=4$, respectively, with $\mathrm{N}-\mathrm{S}$ oriented streets becoming cooler than $\mathrm{E}-\mathrm{W}$ streets as the aspect ratio increases. The building materials of the canyon surfaces were also found to be decisive in the heat storage rate of a street canyon (Arnfield et al. 1998) in the daytime as well as in the nocturnal cooling rate (Arnfield 1990b).

However, field studies dealing directly with outdoor thermal comfort in urban environments are very few. Those focusing on the role of urban geometry are particularly lacking and when available are mostly based on numerical modelling (e.g. Ali-Toudert 2005, AliToudert \& Mayer 2005).

To quantify the effects the thermal environment can have on people, 2 main approaches exist: (1) the physical approach, expressed by means of comfort indices, and (2) the adaptive approach, relying on subjective views gathered from social surveys. Much of the published research involves investigating outdoor comfort using indoor comfort measurements i.e. air temperature, humidity and wind speed (e.g. Swaid et al. 1993, Coronel \& Alvarez 2001, Grundström et al. 2003). Though still used, this approach is unrealistic in sunlit locations because of the additional effects of solar radiation. Indeed, up-to-date human-biometeorological studies using energy-based models emphasize the importance of the radiation fluxes in the human energy balance (Mayer \& Höppe 1987, Jendritzky et al. 1990, Mayer 1993, 1998). Street geometry influences the sensitivities of these fluxes (solar and terrestrial) (Djenane 1998, Pearlmutter et al. 1999, Ali-Toudert 2005, Ali-Toudert \& Mayer 2005). Pearlmutter et al. (1999) showed that the heat gained by a human body within an urban street canyon of $\mathrm{H} / \mathrm{W}=1$ is lower in comparison to a fully exposed location because of more shading within the canyon. Ali-Toudert \& Mayer (2005) compared by means of numerical modelling the thermal environment in a number of shallow and deep street canyons for different orientations. They found that the evolution of comfort in time (during the day) as well as in space (across the canyon) is strongly affected by the aspect ratio and orientation. This is mainly due to the fact that both factors condition the short-wave and long-wave irradiance amounts at street level 
absorbed by a pedestrian. The heat absorbed by a person decreases as shading increases. $T_{\mathrm{a}}$ is found to play a secondary role. $\mathrm{N}-\mathrm{S}$ deep streets are the less uncomfortable, and E-W wide streets are the most stressful.

Recently, more social surveys have been conducted as an alternative methodology for assessing comfort outdoors. Globally, the subjective votes of people confirm the prime importance of the thermal environment (Nikolopoulou et al. 2001, Spagnolo \& de Dear 2003) which is well reproduced by the available rational thermal indices. Yet, they also highlighted the significant role of individual psychophysical aspects in the actual thermal sensation, including available choice, environmental stimulation, thermal history of the person, memory effects of recent weather conditions and expectations. Subjective opinions also revealed that in a warm climate thermal neutrality expressing comfort, i.e. temperature at which people feel neither cold stress nor heat stress, occurs at a warmer index value in outdoor settings compared to indoor settings, and that the zone of comfort is larger, probably because people perceive their lack of control over the climate (Spagnolo \& de Dear 2003).

In our study, we employed a physical approach which highlights the effects of urban structure on comfort and facilitates the connection with design purposes. However, while interpreting the following results, one must bear in mind the uncertainties related to the psychological dimension.

\section{METHODS}

\subsection{Measurements}

As the climatic conditions in the Sahara are relatively homogeneous in summer, the measurements of the necessary meteorological variables were restricted to a few days. Meteorological measurements were carried out on 2 days only (24 and 26 June 2003), which had typical summer conditions, i.e. hot, sunny and cloudless.

Air temperature $\left(T_{\mathrm{a}}\right)$, air humidity $(V P)$ and wind velocity $(v)$ were measured at the human-biometeorologically significant height of $1.2 \mathrm{~m}$ a.g.l. (above ground level). In addition, the mean radiant temperature $T_{\mathrm{mrt}}$ had to be determined precisely because it is an important variable in the human energy balance. The use of a globe thermometer for measuring $T_{\mathrm{mrt}}$ is common (e.g. Nikolopoulou et al. 2001), but this method was dismissed in this investigation because of its inaccuracy outdoors (ASHRAE 2001). $T_{\text {mrt }}$ was determined according to Höppe (1992) and VDI (1998). The surrounding radiant environment was divided into 6 main directions (upwards, downwards and the 4 lateral orientations). All short-wave and long-wave radia- tion fluxes from these 6 directions were recorded by means of a pyranometer and an infrared thermometer, respectively. The long-wave atmospheric radiation was calculated after Oke (1987) as a function of the measured air temperature and air humidity.

$T_{\mathrm{mrt}}\left(\mathrm{in}^{\circ} \mathrm{C}\right)$ was then calculated as follows:

$$
T_{\mathrm{mrt}}=\left[S_{\mathrm{rad}} /\left(\varepsilon_{p} \cdot \sigma\right)^{0.25}\right]-273.2
$$

with

$$
S_{\text {rad }}=\sum_{i=1}^{6} W_{i}\left(a_{K} \cdot K_{i}+a_{L} \cdot L_{i}\right)
$$

where the short-wave $\left(K_{i}\right)$ and long-wave $\left(L_{i}\right)$ radiation flux densities are summed up over the 6 directions (i) as the total radiation flux density $\left(S_{\mathrm{rad}}\right)$. The angle factors $W_{i}$ are the parts of the surroundings in each direction $i$ 'seen' by a human body. For a standing person (approximated to a cylinder shape) $W_{i}$ equals 0.22 for lateral directions and 0.06 upwards and downwards; $a_{K}$ and $a_{L}$ are the short-wave and long-wave absorption coefficients, respectively $\left(a_{K}=0.7\right.$ and $\left.a_{L}=0.97\right) ; e_{p}$ represents the emissivity of the human body $\left(e_{p}=0.97\right)$.

The sky view factor (SVF) was determined for all locations by means of a camera with fish-eye lens. The albedo of the ground had been estimated separately before starting the main measurements as the ratio of short-wave reflected and short-wave global irradiance around noon for each street.

Once $T_{\mathrm{a}}, V P, V$ and $T_{\mathrm{mrt}}$ are known, a thermal index can be calculated. Several thermal indices for outdoor purposes can be used, e.g. the physiologically equivalent temperature, PET (Höppe 1993, 1999), the standard equivalent temperature adapted for outdoors, OUT-SET* (Pickup \& de Dear 1999) or the predicted mean vote also adjusted for outdoors $\mathrm{PMV}^{*}$ (Jendritzky et al. 1990). These indices have some differences but, basically, all rely on the same physical basis, namely the comfort equation of Fanger (Fanger 1970) and incorporate the additional solar radiation fluxes. In this study, PET, based on the human energy balance model MEMI (Munich Energy Model for Individuals), was used. PET is function of the air temperature, air humidity, wind speed and mean radiant temperature and it includes the thermo-physiological processes of a human body in adjusting to stressful thermal conditions. PET is well documented (Höppe 1993, 1999) and has been applied in many urban climate studies (e.g. Mayer \& Höppe 1987, Mayer 1993, Svensson et al. 2003, Mayer et al. 2004, Ali-Toudert \& Mayer 2005).

\subsection{Measuring sites}

According to the objectives of this study, measuring points were selected in 8 locations with various orien- 
Table 1. Geometrical and material properties at all measuring points in the city of Beni-Isguen, Mzab valley, Algeria $\left(32.40^{\circ} \mathrm{N}\right.$, $\left.3.80^{\circ} \mathrm{E}\right)$. $\mathrm{H} 1$ and $\mathrm{H} 2$ are the heights of each of the buildings flanking the street of width W. SVF: sky view factor

\begin{tabular}{|c|c|c|c|c|c|c|}
\hline Points & $\begin{array}{l}\text { Street width W } \\
(\mathrm{m})\end{array}$ & Aspect ratio $\mathrm{H} / \mathrm{W}$ & SVF & $\begin{array}{c}\text { Orientation } \\
\text { (angle from N) }\end{array}$ & $\begin{array}{l}\text { Ground } \\
\text { albedo }\end{array}$ & $\begin{array}{l}\text { Ground } \\
\text { material }\end{array}$ \\
\hline 1 & 2.5 & $\mathrm{H} 1 / \mathrm{W}=1.5 ; \mathrm{H} 2 / \mathrm{W}=0.6$ & 0.45 & $\mathrm{NE}-\mathrm{SW} ; 45^{\circ}$ & 0.15 & concrete \\
\hline 2 & 1.4 & $\mathrm{H} 1 / \mathrm{W}=7.5 ; \mathrm{H} 2 / \mathrm{W}=4.7$ & 0.11 & $\mathrm{~N}-\mathrm{S} ; 166^{\circ}$ & 0.15 & stone + concrete \\
\hline 3 & 2.1 & $\mathrm{H} 1 / \mathrm{W}=3.5 ; \mathrm{H} 2 / \mathrm{W}=3.8$ & 0.13 & NEE-SWW; $63^{\circ}$ & 0.15 & concrete \\
\hline 4 & 1.5 & $\mathrm{H} 1 / \mathrm{W}=1.4 ;$ covered & 0.03 & NW-SE; $130^{\circ}$ & 0.15 & concrete \\
\hline 5 & 2.1 & $\mathrm{H} 1 / \mathrm{W}=4.6 ; \mathrm{H} 2 / \mathrm{W}=3.8$ & 0.16 & NE-SW; $50^{\circ}$ & 0.20 & stone + concrete \\
\hline 6 & 2.4 & $\mathrm{H} 1 / \mathrm{W}=3.1 ; \mathrm{H} 2 / \mathrm{W}=3.5$ & 0.14 & NW-SE; $122^{\circ}$ & 0.15 & concrete \\
\hline 7 & 1.7 & $\mathrm{H} 1 / \mathrm{W}=4.3 ; \mathrm{H} 2 / \mathrm{W}=4.3$ & 0.09 & NW-SE; $125^{\circ}$ & 0.15 & concrete \\
\hline 8 & Market place & $\mathrm{H} 1 / \mathrm{W}=0.1 ; \mathrm{H} 2 / \mathrm{W}=0.1$ & 0.67 & - & 0.25 & stone \\
\hline
\end{tabular}

tations and aspect ratios in the old city of Beni-Isguen, Mzab valley, Algeria (Table 1). The city is built on a hill slope facing east and follows the topography of the site. The measuring points were arranged along a downward measuring route (Fig. 4) with the starting point (Point 1) being the highest (525 $\mathrm{m}$ a.s.l.) and the last point (Point 8) at the market place (484 $\mathrm{m}$ a.s.l.). The city can be divided into 2 parts: the upper part is composed of small houses of irregular shapes (Points 1 to 4 ) and the lower part is almost flat with more regular streets and houses (Points 5 to 8). The urban structure is compact with very narrow streets of various orientations and high aspect ratios. The H/W ratio of the selected streets varies between 7.5 and 0.6 . The building materials are heavy, mostly made of stone. The walls are thick and heavy, covered with a layer of gypsum and painted with light colours (rose, blue or ocher). To get a better impression of the site conditions, Fig. 5 shows some photos of selected measuring sites as well as some fish-eye photos. The meteorological measurements were performed consecutively starting at Point 1 from 6:00 to 24:00 LST and lasting 15 min on average at each site. For each measuring point, the time interval between 2 measurements was about 3 h. Point 8 was considered as a reference site, as it is an unobstructed location.

\section{RESULTS}

Due to only slight differences between the 2 sampling dates (the second day was slightly warmer), only data from the second sampling date were used in the following figures.

\subsection{Air temperatures and air humidity}

Fig. 6 shows the air temperature $T_{\mathrm{a}}$ for all measuring sites. The highest value of $T_{\mathrm{a}}$ was recorded around 15:00 LST at the sunlit Point 1 (Fig. 6). The diurnal course of $T_{\mathrm{a}}$ showed very small differences between the various urban streets in the morning until 11:00 LST. With the increased turbulent transfer of heat induced by the irradiated surfaces (Nakamura \& Oke 1988), the disparity in $T_{\mathrm{a}}$ became larger between nonshaded and shaded streets. A peak difference $\Delta T_{\mathrm{a}}=2$ $\mathrm{K}$ was reached between 15:00 and 16:00 LST. The
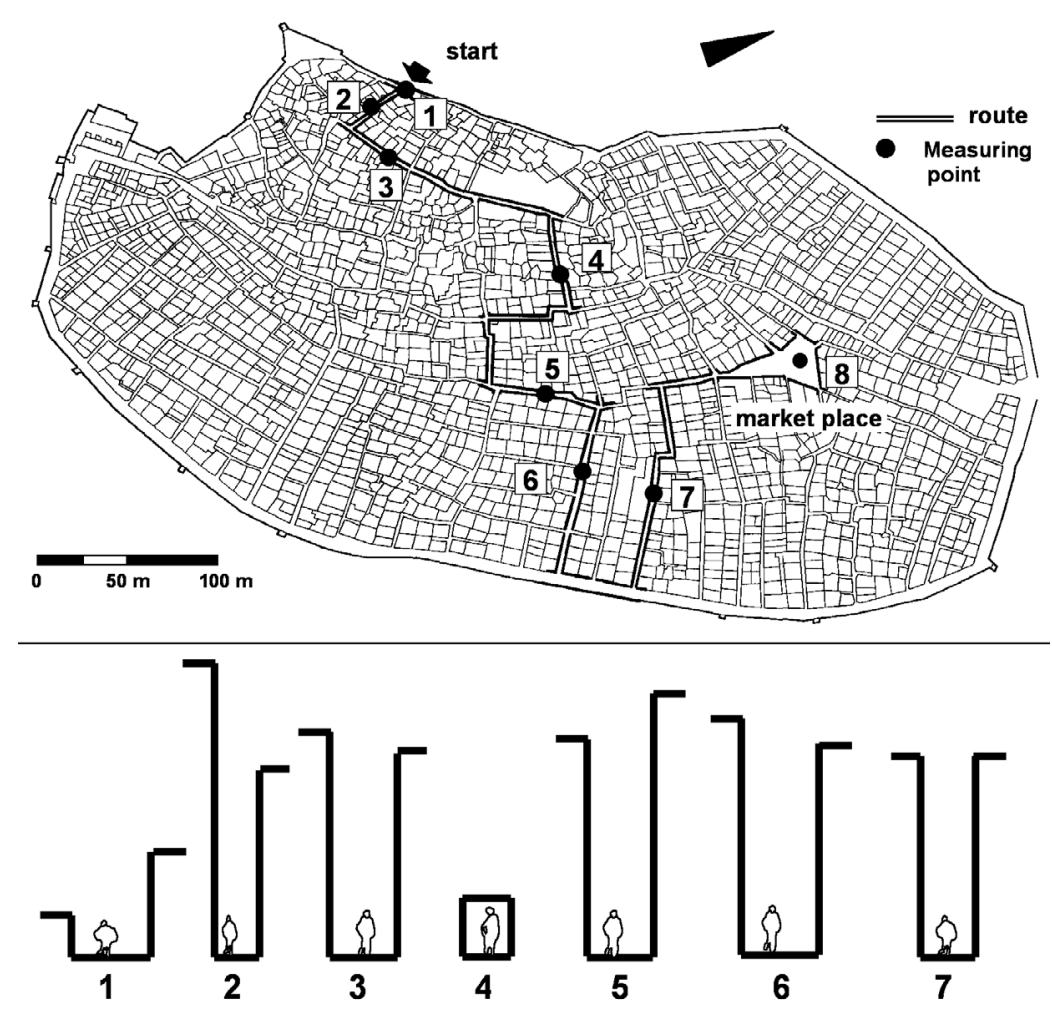

Fig. 4. Route with the measuring points at different street geometries and at the market place in the old city of Beni-Isguen, Mzab valley, Algeria $\left(32.40^{\circ} \mathrm{N}, 3.80^{\circ} \mathrm{E}\right)$ 

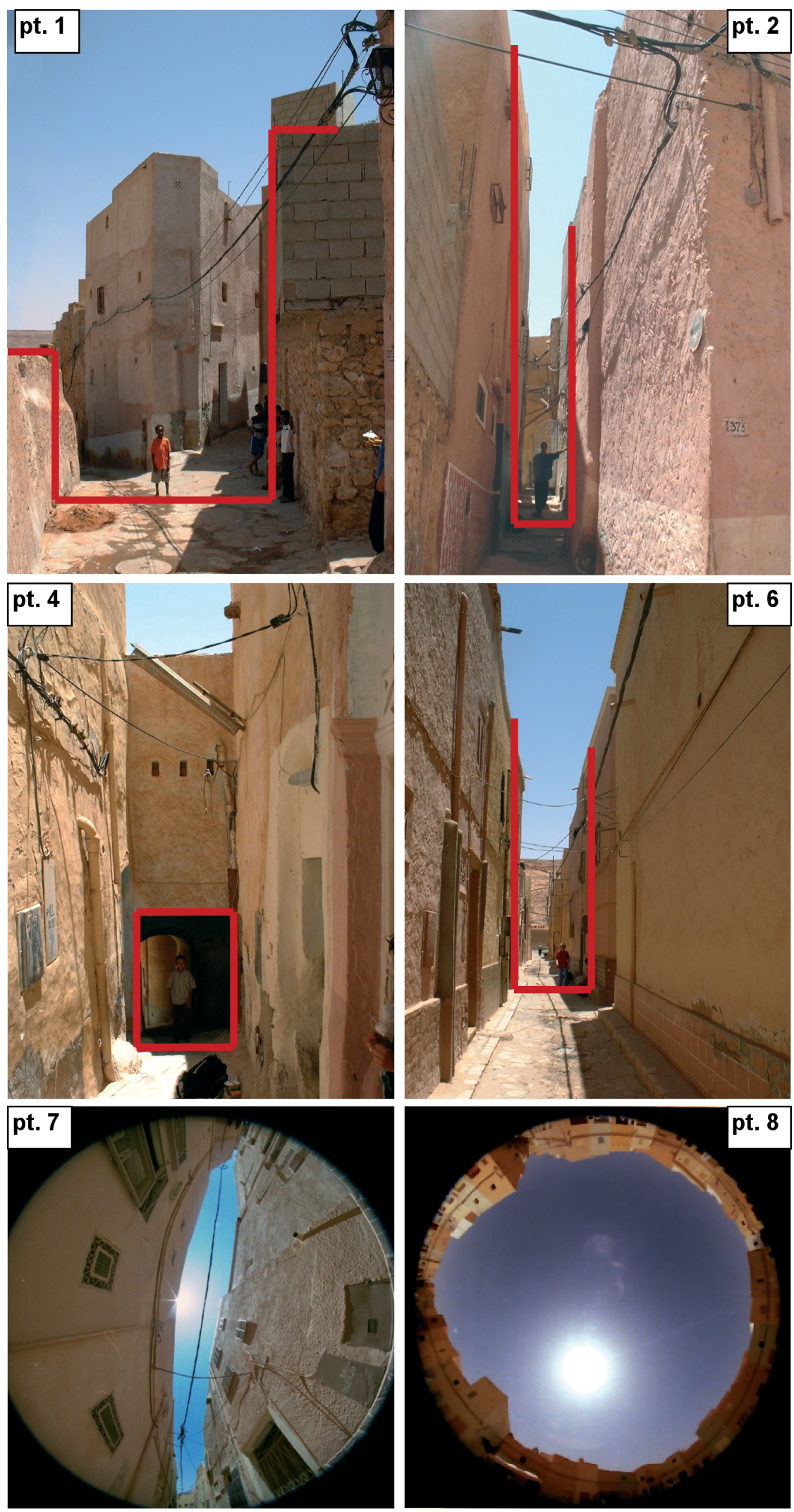

Fig. 5. Photographs and fish-eye photographs of selected measuring sites in the city of Beni-Isguen measuring Points 4 and 5 showed a tendency to be slightly cooler than the others because of their lower exposure to direct solar irradiation. In fact, Point 4 is a covered pathway and Point 5 is a deep canyon oriented close to $\mathrm{N}-\mathrm{S}$, which allows a longer time of protection from direct solar radiation (AliToudert \& Mayer 2005). Point 2, which was the deepest street investigated, was not as cool as expected. This is likely due to its location at the city boundary, which leads to a stronger air mass exchange with the adjacent largely exposed areas. After 21:00 LST, when $T_{\mathrm{a}}$ averages $32.5^{\circ} \mathrm{C}$, almost no difference $\left(\Delta T_{\mathrm{a}}\right)$ was found between all investigated urban streets. The market place (Point 8), however, cooled faster from 22:00 LST and became $1.5 \mathrm{~K}$ cooler at midnight in comparison to the other enclosed measuring points. The SVF at the market place was high $(0.67$, see Table 1) and allows a rapid dissipation of heat. The urban streets have low SVF values and therefore the heat released from the canyon materials is trapped in the canyon air volume.

The vapour pressure (VP) was low and corresponds to the typical water content in this location (Fig. 7). It reached values around $12 \mathrm{hPa}$ in the morning until noontime and was $10 \mathrm{hPa}$ during the night. A systematic influence of the specific site conditions could not be detected. It should be mentioned here that many kitchens are located on the street sides, which, as local sources of heat and humidity, might have influenced these results.

\subsection{Wind speed}

Table 2 lists the wind speed recorded on the 2 days of measurements. The wind speed measured at the unobstructed measuring Point 8 at the market place was temporally more than $5 \mathrm{~m} \mathrm{~s}^{-1}$, while in the urban streets maximum $V$ was up to $4.6 \mathrm{~m} \mathrm{~s}^{-1}$. Although unexpected, this indicates that a ventilation at street level does 
Table 2. Mean wind velocity $\left(\mathrm{m} \mathrm{s}^{-1}\right.$ ) measured at all measuring sites on (a) 23 June and (b) 26 June 2003 in Beni-Isguen. Measurements were conducted following the route shown in Fig. 3, beginning at the local standard time (LST) indicated at the top of the column

\begin{tabular}{|c|c|c|c|c|c|c|c|c|c|c|c|c|c|c|}
\hline \multirow{2}{*}{ Point } & \multicolumn{2}{|c|}{$6 \mathrm{LST}$} & \multicolumn{2}{|c|}{9 LST } & \multicolumn{2}{|c|}{$12 \mathrm{LST}$} & \multicolumn{2}{|c|}{$15 \mathrm{LST}$} & \multicolumn{2}{|c|}{$18 \mathrm{LST}$} & \multicolumn{2}{|c|}{$21 \mathrm{LST}$} & \multicolumn{2}{|c|}{24 LST } \\
\hline & (a) & (b) & (a) & (b) & (a) & (b) & (a) & (b) & (a) & (b) & (a) & (b) & (a) & (b) \\
\hline 1 & 0.0 & 0.8 & 0.3 & 1.1 & 1.8 & 0.5 & 1.0 & 2.8 & 0.8 & 2.0 & 1.3 & 0.9 & 0.1 & 0.2 \\
\hline 2 & 0.3 & 0.8 & 0.5 & 0.4 & 0.1 & 0.6 & 1.2 & 1.9 & 0.1 & 0.9 & 0.3 & 0.1 & 0.1 & 0.3 \\
\hline 3 & 0.3 & 0.4 & 0.8 & 0.5 & 1.2 & 1.8 & 1.2 & 1.7 & 0.7 & 0.5 & 0.4 & 0.4 & 0.1 & 0.3 \\
\hline 4 & 0.6 & 0.5 & 1.5 & 1.8 & 1.7 & 2.7 & 4.6 & 3.5 & 1.5 & 2.3 & 1.2 & 1.4 & 0.8 & 0.6 \\
\hline 5 & 0.5 & 0.3 & 0.8 & 0.9 & 2.2 & 1.9 & 1.4 & 2.9 & 1.6 & 1.1 & 0.8 & 0.2 & 0.5 & 0.1 \\
\hline 6 & 0.9 & 0.6 & 1.7 & 1.3 & 1.7 & 1.7 & 2.1 & 2.0 & 1.2 & 0.3 & 1.0 & 0.2 & 0.7 & 0.2 \\
\hline 7 & 0.7 & 0.8 & 0.5 & 0.6 & 1.1 & 1.5 & 2.0 & 0.9 & 0.6 & 0.4 & 0.4 & 0.7 & 0.7 & 0.2 \\
\hline 8 & 0.4 & 0.1 & 3.4 & 2.9 & 2.3 & 5.6 & 1.2 & 2.3 & 1.5 & 2.5 & 0.5 & 1.5 & 0.7 & 0.1 \\
\hline
\end{tabular}

exist despite the high compactness of the urban structure. Point 4 is worth mentioning: even though covered and enclosed, it turns out to be a 'windy' site, being the best ventilated of all streets investigated. This may be (1) because of its location at the limit between the high and low part of the city, which means that the buildings downhill do not obstruct the incoming wind flow, and (2) because the street canyon faces the main wind direction, i.e. east.

\subsection{Surface temperatures}

The surface temperatures of the ground $\left(T_{\mathrm{s}}\right)$ and of the 2 walls $\left(T_{\mathrm{w}}\right)$ are given in Fig. 8 and inform on the exposure versus shading of the canyon facets (Nakamura \& Oke 1988, Yoshida et al. 1990/1991). In the morning, street surface temperatures showed relatively small differences between all urban canyons. Points 8 and 1 showed maximum values around 50 to $55^{\circ} \mathrm{C}$ in the afternoon, whereas Point 4 experienced $T_{\mathrm{s}}$ of about $34^{\circ} \mathrm{C}$ at the same time in the afternoon, i.e. 3 to $4 \mathrm{~K}$ lower than $T_{\mathrm{a}}$. Fig. 8 shows that the street surface can be irradiated even for deep canyons, i.e. at Points 5, 6 and 7 at midday hours (12.00 to $13: 00 \mathrm{LST}$ ), but $T_{\mathrm{s}}$ values were below $46^{\circ} \mathrm{C}$ because of their short duration of exposure.

The temperatures of the canyon wall surfaces showed generally small differences between both sides when shaded. In this case, $T_{\mathrm{w}}$ values are below the corresponding air temperature for each measuring point as observed by others (e.g. Yoshida et al.
1990/1991). For a subtropical latitude, high aspect ratios combined with a high sun position result in a good protection of the façades in comparison to the ground surface as reported by the numerical studies of Arn-

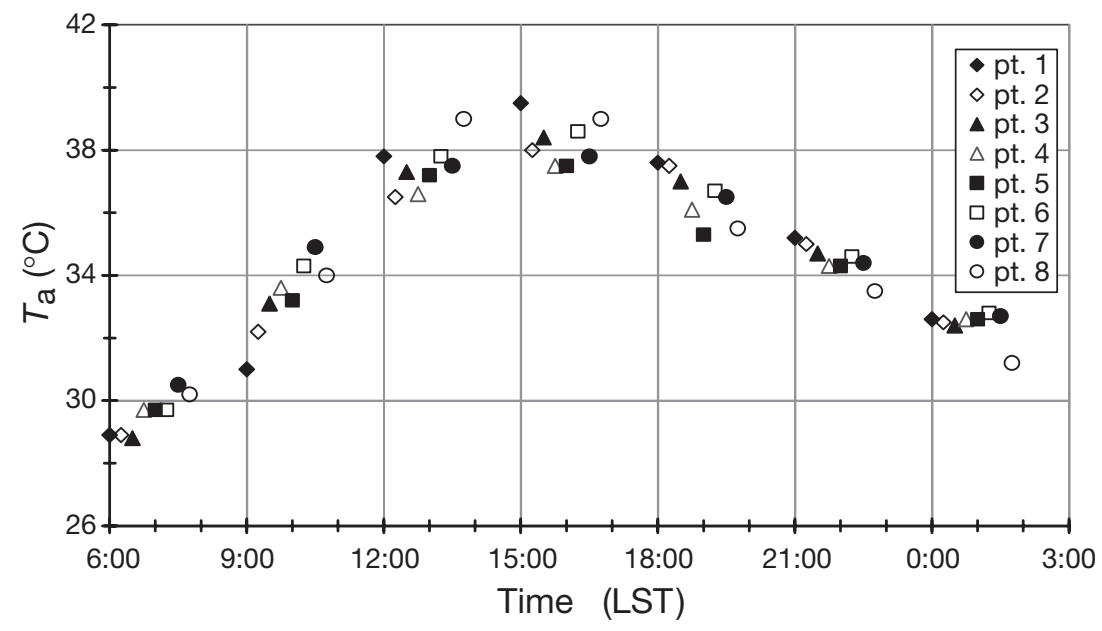

Fig. 6. Air temperature $\left(T_{\mathrm{a}}\right)$ at $1.2 \mathrm{~m}$ a.g.l. (above ground level) during a typical summer day in the old city of Beni-Isguen

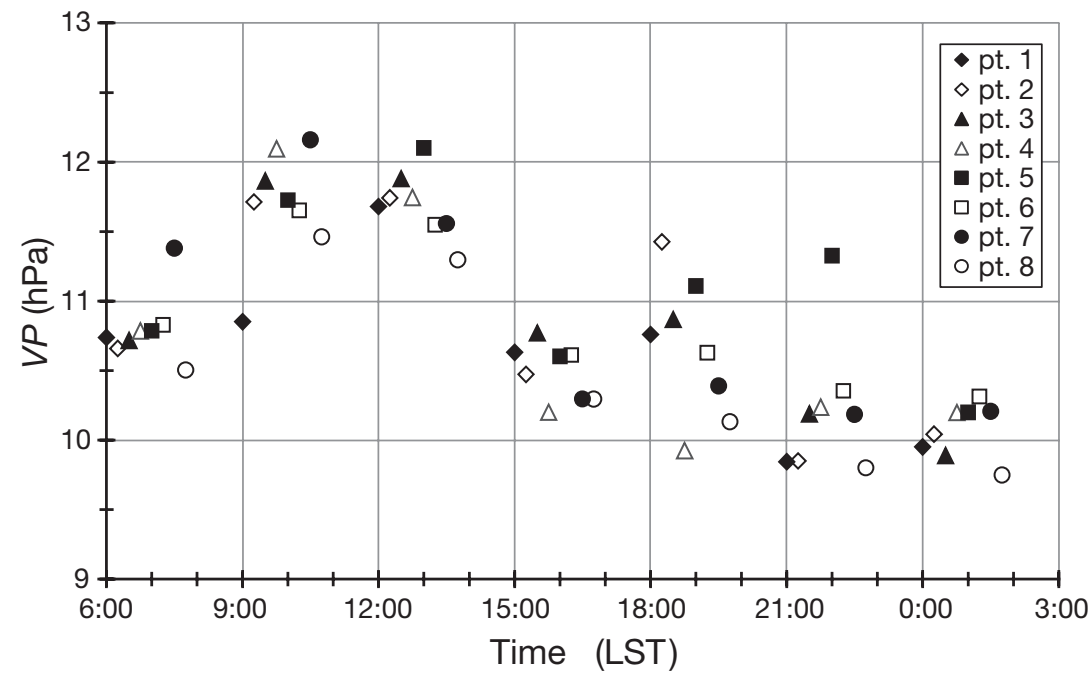

Fig. 7. Vapour pressure $(V P)$ at $1.2 \mathrm{~m}$ a.g.l. during a typical summer day in the old city of Beni-Isguen 
field (1990a) and Bourbia \& Awbi (2004). Point 4 showed almost the same $T_{\mathrm{w}}$ values as $T_{\mathrm{s}}$. At Point $1, \Delta T_{\mathrm{w}}$ between both walls was much larger (up to $11 \mathrm{~K}$ ) because of its large SVF which allows a longer period of solar irradiation of the south-east facing wall. In the evening all surfaces were warmer than the air by few degrees except at Point 8 where $T_{\mathrm{a}}$ and $T_{\mathrm{s}}$ were almost equal.

\subsection{Radiation fluxes}

The heat gained by a human body consists of short-wave irradiance $\left(K_{\mathrm{abs}}\right)$ due to the exposure to direct and diffuse solar radiation and to long-wave irradiance $\left(L_{\mathrm{abs}}\right)$ absorbed from heatemitting surrounding surfaces. For a better understanding of the role of both components on the total energy absorbed by a standing person, the 2 quantities are represented separately in Figs. 9 and 10.

At the subtropical location of BeniIsguen, the sky is clear and the global radiation in the summer is dominated by the direct solar radiation, while the diffuse radiation is very small. Hence, $K_{\text {abs }}$ depends strongly on the course of the sun and on canyon geometry and orientation. The unobstructed market place (SVF: 0.67) showed the highest $K_{\text {abs }}$ values, namely $215 \mathrm{~W} \mathrm{~m}^{-2}$ in the morning (8:00 LST) and a maximum of $260 \mathrm{~W} \mathrm{~m}^{-2}$ around 11:00 LST. The high $K_{\text {abs }}$ value recorded at 8:00 LST and around 17:00 LST at the market place is due to the relatively low sun height $\left(\sim 25^{\circ}\right.$ to $\left.35^{\circ}\right)$, which increases the amount of energy absorbed laterally by a standing person. At Point 1, which also had a relatively high SVF value (0.45), $K_{\text {abs }}$ reached $257 \mathrm{~W} \mathrm{~m}^{-2}$ at 15:00 LST. At all other measuring points, $K_{\text {abs }}$ is clearly lower and did not exceed $60 \mathrm{~W} \mathrm{~m}^{-2}$, except at noontime when the sun is at its highest position $\left(\sim 75^{\circ}\right)$. At this time, Points 2, 3 and 5 were irradiated despite their high aspect ratios. These results suggest that a deep geometry has the advantage of shortening the period of direct exposure to the sun regardless of the orientation.
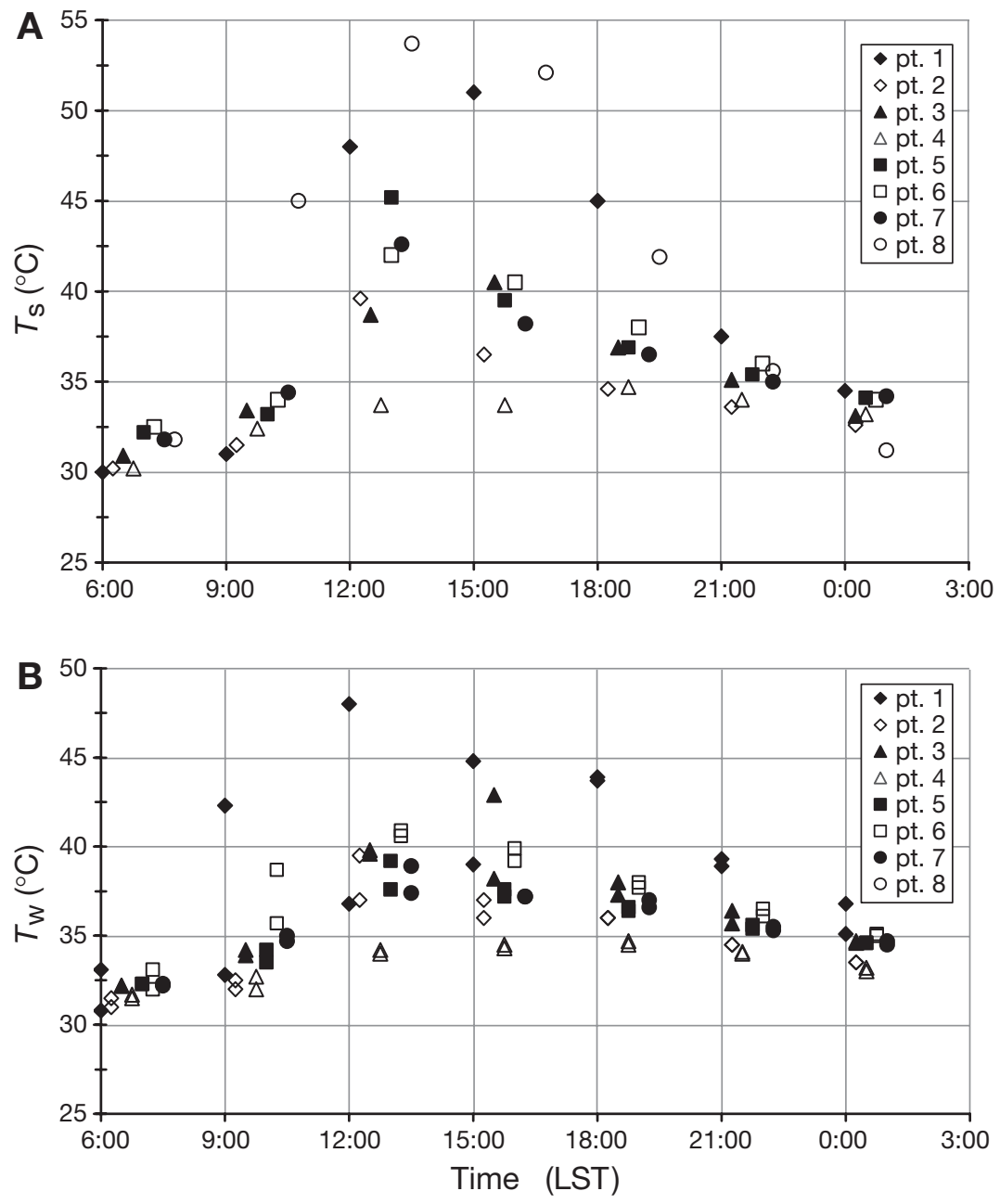

Fig. 8. (A) Ground surface temperature $\left(T_{\mathrm{s}}\right)$ and (B) wall surface temperature $\left(T_{\mathrm{w}}\right)$ during a typical summer day in the old city of Beni-Isguen

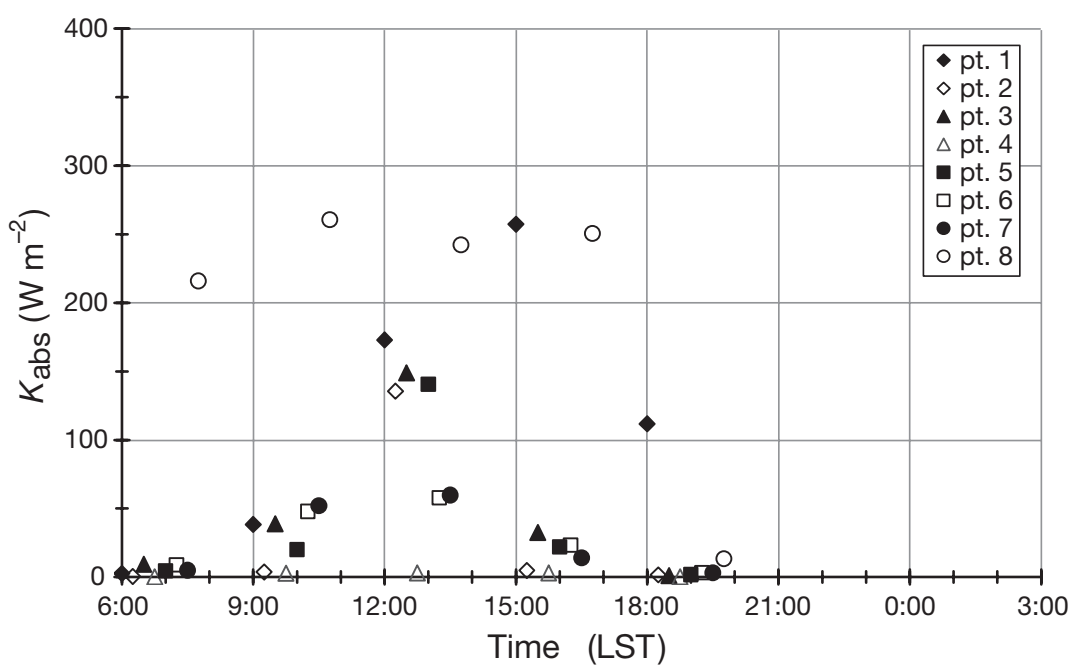

Fig. 9. Short-wave radiation fluxes $\left(K_{\text {abs }}\right)$ absorbed by a standing person at $1.2 \mathrm{~m}$ a.g.l. during a typical summer day in the old city of Beni-Isguen 


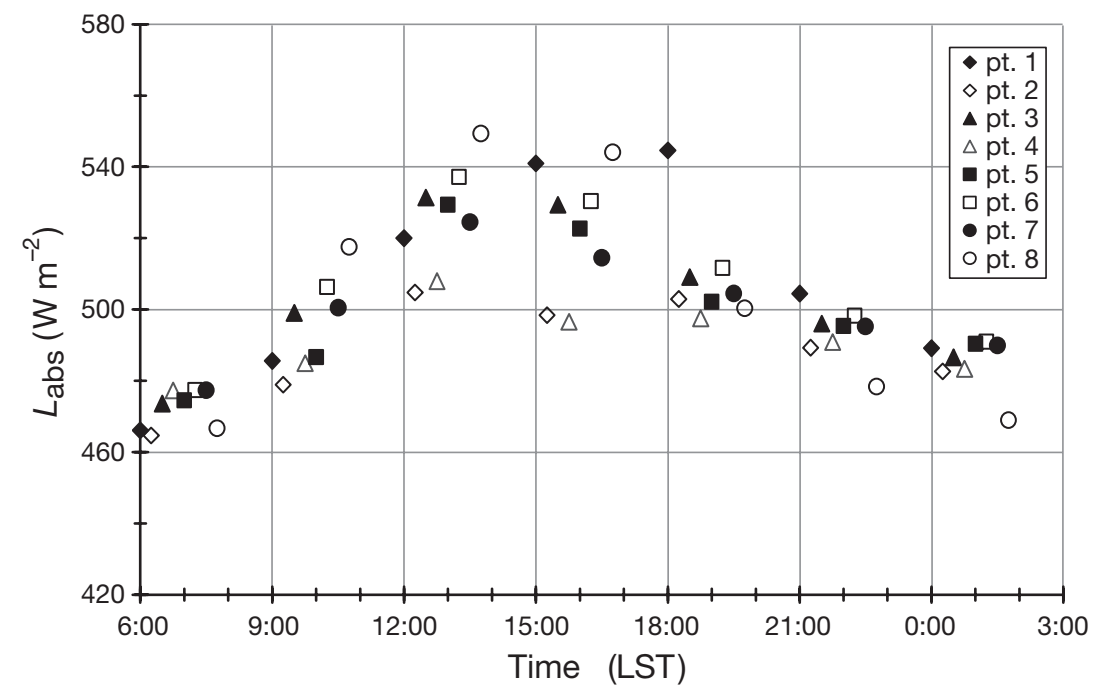

Fig. 10. Long-wave radiation fluxes ( $\left.L_{\text {abs }}\right)$ absorbed by a standing person at $1.2 \mathrm{~m}$ a.g.l. during a typical summer day in the old city of Beni-Isguen

(Point 8) experienced the highest $T_{\mathrm{mrt}}$ values ranging between 60 and $75^{\circ} \mathrm{C}$ from $8: 00$ to 17:00 LST. The high $T_{\mathrm{mrt}}$ values in the morning were due to the lateral irradiation of the standing person when the sun is still relatively low (cf. Fig. 9). In more detail, $T_{\text {mrt }}$ differences between the different urban streets are clearly higher than $\Delta T_{\mathrm{a}}$. The lowest $T_{\mathrm{mrt}}$ values were calculated for Point 4, corresponding to the lowest $K_{\mathrm{abs}}$ und $L_{\mathrm{abs}}$ values. This is not surprising since Point 4 is a covered pathway (SVF: 0.03) and is not directly influenced by solar radiation. At this location, $T_{\text {mrt }}$ showed a 'flat' diurnal course with values varying between 32 and $37^{\circ} \mathrm{C}$. Point 2 is as protected as Point 4, except at midday, at which time $T_{\text {mrt }}$ reaches $55^{\circ} \mathrm{C}$. This is due to the $\mathrm{N}-\mathrm{S}$ orientation of this urban street canyon which prevents shadowing even though the canyon is very deep. The role of the orientation can also be seen for Points 6 and 7 . Their

In contrast to $K_{\mathrm{abs}}$ the pattern of the daily course of the long-wave radiation fluxes ( $L_{\mathrm{abs}}$ ) absorbed by a standing person (Fig. 10) is different. $L_{\text {abs }}$ was generally higher and reached values between 460 and $550 \mathrm{~W} \mathrm{~m} \mathrm{~m}^{-2}$. No systematic $L_{\mathrm{abs}}$ difference could be found between the various street canyons, probably because of the high thermal admittance of the building materials, which clearly levelled the daily surface temperatures in contrast to the larger fluctuations of $T_{\mathrm{a}}$. However, the streets at Points 2 and 4 clearly released less heat than streets at other measuring points in the afternoon hours as these had lower surfaces temperatures. Moreover, the daily amplitudes of $L_{\text {abs }}$ were relatively low, also being a logical consequence of the high thermal inertia of the urban canyon materials. The market place showed lower $L_{\text {abs }}$ values in the early morning and during the night because the larger SVF leads to a faster nocturnal cooling.

\subsection{Mean radiant temperature}

As expected, the mean radiant temperature $T_{\mathrm{mrt}}$ (Fig. 11) was noticeably lower within the urban streets than in an unobstructed location (e.g. Point 1 vs. Point 8). The difference between sheltered and exposed measuring points reached $36 \mathrm{~K}$ at the hottest time of the day (e.g. between Points 1 and 2 around 15:00 LST). The market place

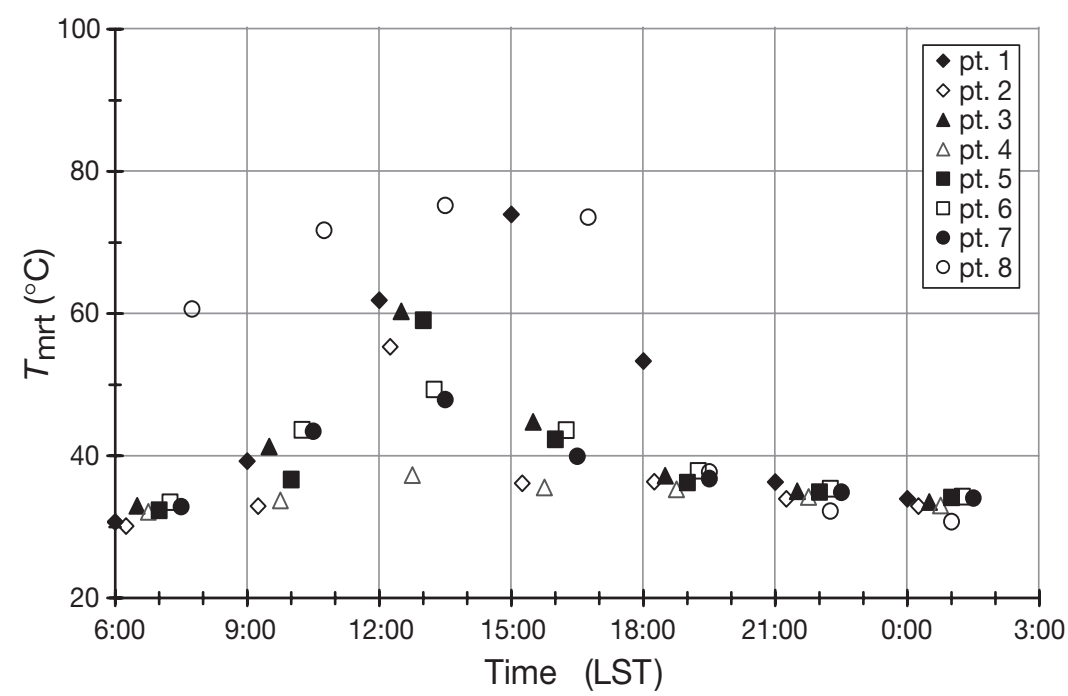

Fig. 11. Mean radiant temperature $\left(T_{\mathrm{mrt}}\right)$ at $1.2 \mathrm{~m}$ a.g.l. during a typical summer day in the old city of Beni-Isguen
NW-SE orientation leads to a lower amount of energy being gained by a human body, particularly in the early afternoon, in contrast to higher energy gain for measuring Points 1, 3 and 5 (nearly NE-SW oriented). After 18:00 LST, negligible differences were registered between all urban streets and $T_{\mathrm{mrt}}$ averaged $35^{\circ} \mathrm{C}$. Indeed, the solar radiation intensity is less and the low sun position promotes shade at street level. Yet, the deep geometry has partly inhibited the influence of the orientation, as well as the discontinuous measurements.

The diurnal fluctuations of $T_{\mathrm{mrt}}$ as well as $T_{\mathrm{mrt}}$ maxima are mainly attributable to $K_{\mathrm{abs}}$ (Fig. 9), whereas 
$T_{\text {mrt }}$ minima depend on $L_{\text {abs }}$ (Fig. 10). The latter rely on the thermal admittance of the building materials and on SVF. Compared to low admittances (usually light materials), high admittances reduce the heat emitted from the surfaces in the daytime, which extends to the night-time period.

In the daytime, $T_{\mathrm{mrt}}$ was for the most part higher than $T_{\mathrm{a}}$ (Fig. 12). By night $T_{\mathrm{mrt}}$ was approximately equal to $T_{\mathrm{a}}$. $T_{\mathrm{mrt}}$ was a few degrees higher in the shade in the urban canyons and up to $14 \mathrm{~K}$ higher in irradiated situations. Points 2 and 4 had even lower values (1.5 to $2 \mathrm{~K}$ ) shortly around 15:00 LST because of their confined aspects. At the market place, the difference $\left(T_{\mathrm{mrt}}-T_{\mathrm{a}}\right)$ reached $38 \mathrm{~K}$, which occurred around 11:00 LST.

\subsection{Thermal comfort analysis}

As previously shown, PET schemes are basically influenced by $T_{\mathrm{mrt}}$ in summer under sunny conditions. Therefore, the patterns of the diurnal courses of PET (Fig. 13) and $T_{\mathrm{mrt}}$ (Fig. 11) are similar. Regressions analyses between PET and $\mathrm{T}_{\mathrm{mrt}}$ lead to coefficients of determination of $\mathrm{R}^{2}=0.900$ for a linear relationship and $\mathrm{R}^{2}=0.939$ for a logarithmic relationship. This is not surprising, as $T_{\mathrm{a}}, V P$ and $V$ vary comparatively much less.

The most uncomfortable locations were those exposed to the sun. PET peak values, occurred in the afternoon and ranged from 53 to $55^{\circ} \mathrm{C}$ at Point 8 (market place, SVF: 0.67 ) and $54^{\circ} \mathrm{C}$ at Point 1 (SVF: 0.45). These high values were mitigated by high wind speed (i.e. $5.6 \mathrm{~m} \mathrm{~s}^{-1}$ at Point 8, $2.8 \mathrm{~m} \mathrm{~s}^{-1}$ at Point 1). By contrast, the lowest PET value $\left(37^{\circ} \mathrm{C}\right)$ was determined for Point 4 (SVF: 0.03). In the early morning and late afternoon, PET did not reveal clear differences between the sites within street canyons, i.e. $\mathrm{PET} \approx 30^{\circ} \mathrm{C}$ before 8:00 LST and $\approx 36^{\circ} \mathrm{C}$ after $18: 00$ LST.

PET differences between the various streets were more pronounced around noon at Points 1, 2, 3 and 5, indicating a higher level of heat stress $(\sim 45$ to $51^{\circ} \mathrm{C}$ ). Points 6 and 7 showed a slighly lower level of heat stress $1 \mathrm{~h}$ later $\left(<45^{\circ} \mathrm{C}\right)$. PET values decreased very slowly in the night-time and roughly equalled the air temperature at midnight.

\section{DISCUSSION AND CONCLUSIONS}

On-site meteorological measurements were carried out in an old desert city. For the first time, a humanbiometeorological based method was applied in a vernacular desert city with the goal of investigating the effectiveness of traditional design solutions in ensuring comfortable outdoor conditions. This experimental work provides quantitative information on this issue and suggests a number of potential future investigations.

Quantitatively, the results show a high thermal discomfort in a non-shaded location at a subtropical latitude of $32.40^{\circ} \mathrm{N}$ under summer conditions, with $T_{\mathrm{mrt}}$ and PET reaching a maximum of 74 and $55^{\circ} \mathrm{C}$, respectively. In the absence of shading, heat stress is experi-

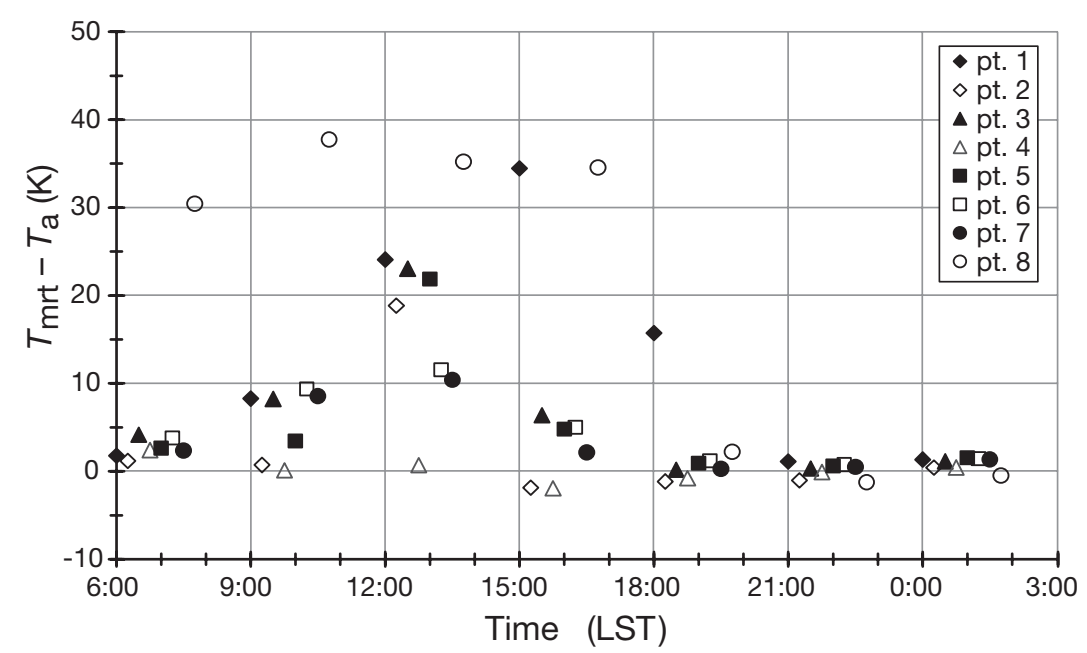

Fig. 12. Difference between mean radiant temperature (in $\mathrm{K})\left(T_{\mathrm{mrt}}\right)$ and air temperature $\left(T_{\mathrm{a}}\right)$ at $1.2 \mathrm{~m}$ a.g.l. during a typical summer day in the old city of Beni-Isguen

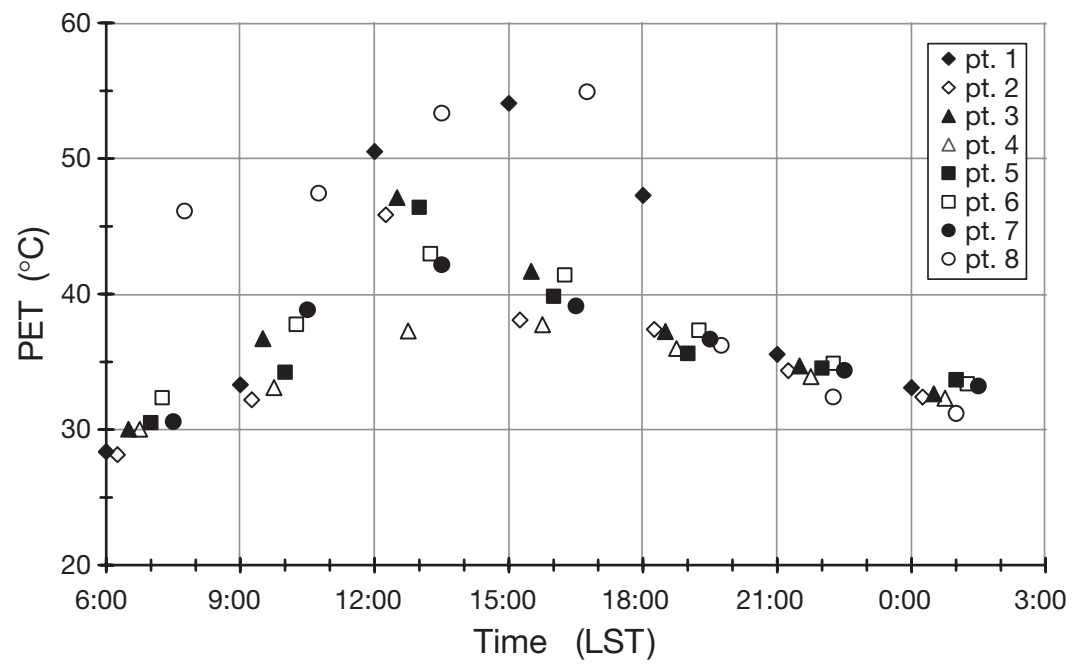

Fig. 13. Physiologically equivalent temperature (PET) at $1.2 \mathrm{~m}$ a.g.l. during a typical summer day in the old city of Beni-Isguen 
enced in the morning hours and lasts for a large part of the day. This field study confirms that shading achieved by means of high aspect ratios is an efficient strategy to reduce the thermal discomfort of people at street level.

The heat gained by a standing person depends on (1) the exposure of the body itself and (2) the exposure of the surrounding urban surfaces. Interestingly, the distinct representation of the absorbed short-wave and long-wave irradiances revealed that the long-wave radiation is a significant source of heat load and the absolute values largely exceed the short-wave irradiance absorbed. Hence, shading the surrounding urban surfaces is as crucial as shading the person in mitigating the heat stress.

High aspect ratios were found to be an effective strategy in shortening the duration of exposure to solar energy and mostly affected the amount of absorbed short-wave irradiance. The very high aspect ratios investigated have partly inhibited the influence of the orientation. However, it was observed that the $\mathrm{N}-\mathrm{S}$ orientation is the most comfortable except around noon, and a NE-SW oriented street is more stressful than a NW-SE one. This is in good agreement with results obtained by modelling (Ali-Toudert 2005, AliToudert \& Mayer 2005).

Moreover, covered streets experience the lowest PET values as the heat emitted from these surfaces is noticeably lower in comparison to other canyons and the sheltered site is almost not influenced by the daily course of solar radiation. This corroborates the usefulness of galleries as pedestrian pathways.

Thick and heavy materials with high thermal capacities help decrease the long-wave radiant heat during the day and minimize the differences between the streets of different geometries and orientations. However, when high thermal capacity is combined with high aspect ratios, the heat released from the canyon surfaces in the night-time is slowed and delays the nocturnal cooling of the urban fabric. Although nighttime outdoor comfort is of small relevance in comparison to day-time, the cooling of the houses would last longer and would extend the period of night-time discomfort indoors as reported by Meier et al. (2004).

Contrary to common opinion, air temperature was found to be moderately lower in the urban canyons in comparison to a free location $\left(\Delta T_{\max }=2 \mathrm{~K}\right)$. No clear correlation could be found between the aspect ratio and the air temperature. This contrasts with the higher air temperature differences reported by Coronel \& Alvarez (2001) and Grundström et al. (2003). Furthermore, $T_{\mathrm{a}}$ as a conservative quantity reacts little to urban geometry and can therefore be used only as a secondary indicator for comfort outdoors. Indeed, the reason why $T_{\mathrm{a}}$ is still often used as the main comfort indicator is probably that any decrease of $T_{\mathrm{a}}$ is almost always associated with increased shading and hence lower irradiances.

The present study is based on an energy-model approach which assesses comfort by means of comfort indices. Subjective aspects that may affect the actual thermal sensation of people and revealed by social surveys to be important (e.g. Nikolopoulou et al. 2001, Spagnolo \& de Dear 2003) are not dealt with in the present paper. Social surveys will bring more knowledge on the reliability of these indices and refine their scaling. Such work is particularly lacking in such severe climates, where people's subjective perception of the climate may play an important role in their sensation of comfort versus discomfort.

Vernacular architectures provide valuable knowledge on climate-conscious design, and this study draws attention to issues still needing further investigation, for instance:

Comparing old and new typologies in the Mzab valley. This is particularly relevant for the region where the new settlements contrast strongly with the old cities. These typologies have noticeably larger urban plan densities and open spaces and make more use of vegetation. These also imply a different use, e.g. the open spaces are more appropriate for social frequentation and motorised traffic.

This study shows some evidence for existing urban ventilation in the city's streets in spite of the high density of the urban fabric. Moreover, this work shows that more continuous measurements are needed for establishing the dependence between air temperature and the urban structure.

The introductory part of this paper highlighted the strong interdependence between all design concepts and between the various scales. An exhaustive assessment of the effectiveness of these design concepts should deal simultaneously with the indoor and outdoor climates, e.g. at a neighbourhood scale, and include summer and winter issues, i.e. internal and external thermal and visual comfort, ventilation, etc. Such extensive studies are lacking.

Acknowledgements. The authors gratefully acknowledge the Association for the protection of the environment of the city of Beni-Isguen, Algeria, and M. Omar Douag for their valuable help. The Architecture Office ARCHIMED, Ghardaia, kindly provided Fig. 1. Thanks also go to the German Academic Exchange Service (DAAD) for the scholarship granted to F. Ali-Toudert.

\section{LITERATURE CITED}

Aida M, Gotoh K (1982) Urban albedo as a function of the urban structure-a two dimensional numerical simulation. Boundary-Layer Meteorol 23:415-424 
Ali-Toudert F (2005) Dependence of outdoor thermal comfort on street design. PhD Thesis, University of Freiburg, Freiburg

Ali-Toudert F, Mayer H (2005) Numerical study on the effects of aspect ratio $\mathrm{H} / \mathrm{W}$ and orientation of an urban street canyon on outdoor thermal comfort. Building Environ (in press)

Arnfield J (1990a) Street design and urban canyon solar access. Energy Building 14:117-131

Arnfield (1990b) Canyon geometry, the urban fabric and nocturnal cooling: a simulation approach. Phys Geography 11:220-239

Arnfield J, Herbert JM, Johnson GT (1998) A numerical simulation investigation of urban canyon energy budget variations. Proc 13th Conf on Biometeorology and Aerobiology, Albuquerque, New Mexico. American Meteorological Society, Boston, MA, p 2-5

ASHRAE (2001) Measurements and instruments. In: Handbook of fundamentals. American Society for Heating, Refrigerating and Air Conditioning, Atlanta, GA, p 13.26-13.27

Bourbia F, Awbi HB (2004) Building cluster and shading in urban canyon for hot dry climate. Part 2: shading simulations. Renewable Energy 29:291-301

Coronel JF, Alvarez S (2001) Experimental work and analysis of confined urban spaces. Sol Energy 70:263-273

Donnadieu C, Donnadieu P, Didillon JM (1977) Habiter le désert, maisons Mozabites. Mardaga, Paris

Djenane M (1998) Participation de la forme urbaine au contrôle de l'irradiation solaire. Référence particulière au rôle de la rue dans les régions chaudes et sèches. Mémoire de magister. Centre universitaire Mohamed Khider, Biskra

Fanger PO (1970) Thermal comfort. Danish Technical Press, Copenhagen

Givoni B (1997) Climate considerations in building and urban design. Van Nostrand Reinhold, New York

Golany G (1982) Design for arid regions. van Nostrand Reinhold, New York

Golany G (1996) Urban design morphology and thermal performance. Atmos Environ 30:455-465

Grundström K, Johansson E, Mraisi M, Ouahrani D (2003) Climat et urbanisme-la relation entre confort thermique et la forme du cadre bâti. Report 8, Housing Development and Management, Lund University, Lund

Höppe P (1992) Ein neues Verfahren zur Bestimmung der mittleren Strahlungstemperatur im Freien. Wetter Leben 44:147-151

Höppe P (1993) Heat balance modelling. Experientia 49: $741-746$

Höppe P (1999) The physiological equivalent temperature-a universal index for the biometeorological assessment of the thermal environment. Int J Biometeorol 43:71-75

Jendritzky G, Menz G, Schirmer H, Schmidt-Kessen W (1990) Methodik zur räumlichen Bewertung der thermischen Komponente im Bioklima des Menschen. Fortgeschriebenes Klima-Michel-Modell. Beiträge der Akademie für Raumforschung und Landesplanung, Hannover

Krishan (1996) The habitat of two deserts in India: hot-dry desert of Jaisalmer (Rajasthan) and the cold-dry high altitude mountains desert of Leh (Ladakh). Energy Buildings 23:217-229

Koenigsberger $\mathrm{OH}$, Ingersoll $\mathrm{TG}$, Mahyew A, Sokolay SV (1973) Manual of tropical housing and Building. Part 1: climatic design. Lorgman, London

Mayer H, Höppe P (1987) Thermal comfort of man in different urban environments. Theor Appl Climatol 38:43-49

Mayer H (1993) Urban bioclimatology. Experientia 49: 957-963
Mayer H (1998) Human-biometeorological assessment of urban microclimates according to the German VDIguideline 3787 part II. Second Urban Environment Symposium, Albuquerque, New Mexico, November 2-6. American Meteorological Society, Boston, MA, p 136-139

Mayer H, Holst T, Rost J, Imbery F, Ali-Toudert F (2004) Thermal comfort conditions in an E-W oriented street canyon in Freiburg (Germany) during the European summer heatwave 2003. Proc 5th Symp on the Urban Environment, Vancouver, Canada, 23-28 August. American Meteorological Society, Boston, MA, p 1-2

Meier IA, Roaf SC, Gileard I, Runsheng T, Stavi I, MackenzieBennett J (2004) The vernacular and the environment towards a comprehensive research methodology. de Wit $\mathrm{MH}$ (ed) Proc 21st Int Conf Passive and Low Energy Architecture (PLEA), Eindhoven, 19-22 September. PLEA, Eindhoven, p 719-724

Nakamura Y, Oke T (1988) Wind, temperature and stability conditions in an east-west oriented urban canyon. Atmos Environ 22:2691-2700

Nikolopoulou M, Baker N, Steemers K (2001) Thermal comfort in outdoor urban spaces: understanding the human parameter. Sol Energy 70:227-235

Nunez M, Oke T (1977) The energy balance of an urban canyon. J Appl Meteorol 16:11-19

ONM (1985) Atlas climatologique national, Station Ghardaia, partie 1: recueil de données. Office national de la Météorologie, Alger

Oke T (1987) Boundary layer climates. Routledge, London

Ouahrani D (1993) Light and housing in the desert: case study of Ghardaia, Algeria. Light Res Technol 25:1-11

Pearlmutter D, Bitan A, Berliner P (1999) Microclimatic analysis of 'compact' urban canyons in an arid zone. Atmos Environ 33:4143-4150

Pickup J, de Dear R (1999) An outdoor thermal comfort index (OUT-SET*). Part 1: The model and its assumptions. In: de Dear R, Potter JC (eds) Proc 15th Int Congress on Biometeorology \& Int Conf on Urban Climatology, 8-12 November, Sydney. Macquarie University, Sydney, p 279-283

Potchter O, Tepper Y (2002) The climatic behaviour of the internal courtyard in extremely hot and dry zones. In: GRECO/ACAD (eds) Proc 19th Int Conf of Passive and Low Energy Architecture (PLEA), Toulouse. PLEA, Toulouse, p 469-473

Ravérau A (1981) Le Mzab, une leçon d'architecture. Sindbad, Paris

Roche M (1973) Le M'zab, architecture ibadite en Algérie. Arthaud, Strasbourg

Santamouris M, Papanikolaou N, Koronakis I, Livada I, Asimakopoulos D (1999) Thermal and air flow characteristics in a deep pedestrian canyon under hot weather conditions. Atmos Environ 33:4503-4521

Svensson MA, Thorsson S, Lindqvist S (2003) A geographical information system model for creating bioclimate mapsexamples from a high mid-latitude city. Int J Biometorol 47:102-112

Spagnolo J, de Dear R (2003) A field study of thermal comfort in outdoor and semi-outdoor environments in subtropical Sydney Australia. Building Environ 38:721-738

Swaid H, Bar-El M, Hoffman ME (1993) A bioclimatic design methodology for urban outdoor spaces. Theor Appl Climatol 48:49-61

Taha MR, Douglas S, Haney J (1997) Mesoscale meteorological and air of quality impacts of increased urbane albedo and vegetation. Energy Buildings 25:169-177 
Todhunter PE (1990) Microclimatic variations attributable to urban canyon asymmetry and orientation. Phys Geogr 11:131-141

VDI (Verein Deutscher Ingenieure) (1998) Methods for the human-biometeorological assessment of climate and air

Editorial responsibility: Chris de Freitas, Auckland, New Zealand quality for urban and regional planning, part 1: climate. VDI 3787 Part 2, Beuth, Berlin

Yoshida A, Tominaga K, Watani S (1990/1991) Field measurements on energy balance of an urban canyon in the summer season. Energy Buildings 15/16:417-423

Submitted: December 9, 2004; Accepted: April 12, 2005

Proofs received from author(s): May 16, 2005 